\title{
Obstacles in Implementing the School Committee Policy on Primary School in Banda Aceh
}

\author{
Fadhillah $^{1}$, Putry Julia ${ }^{1}$, Nurhattati Fuad ${ }^{2}$, Rugaiyah ${ }^{2}$ \\ \{fadhillah@serambimekkah.ac.id $\left.{ }^{1}\right\}$ \\ ${ }^{1}$ Teacher Training and Education Faculty, Universitas Serambi Mekkah, Imum Lueng Bata Street, Banda \\ Aceh, Indonesia \\ ${ }^{2}$ Postgraduate of Education, Universitas Negeri Jakarta, Jakarta, Indonesia
}

\begin{abstract}
This study aims to analyze the readiness and constraints of principals, teachers and school committees and communities in implementing policies related to school committees at Primary School in Banda Aceh. A qualitative research approach with a survey method in which the research subjects consisted of principals, teacher representatives, school committees and parents of students who were randomly selected at five elementary schools in the city of Banda Aceh. Data collection was carried out starting from 2017 until mid 2018 through interviews, questionnaires for seminars and Focus Group Discussion (FGD). Furthermore, the data were analyzed using the Miles and Huberman methods. The results showed that the fundamental problems that the effectiveness of school citizens in implementing school committee policies are the lack of knowledge about school committee policies, lack of knowledge in arranging school programs based on the School Internal Quality Evaluation (EMIS) and not synergizing school committees at the beginning of school programming and model problems Information communication systems that have not yet existed among school citizens with relevant parties that are involved hinder the coordination between school and the community who have the opportunity to assist school activities.
\end{abstract}

Keywords:Obstacles, Implementation, School Committee Policy, Community Partisipation.

\section{Introduction}

The school committee's policy is part of determining the policy of community participation in education. The community is required to play an active role in education. Community involvement in education, especially parents of students allegedly can improve student academic achievement. In line with several research results which stated that "the relationship between parental involvement and academic achievement was found to be consistent across different levels of levels and ethnic groups. However, the strength of varied relationships based on the type of assessment is used to measure student achievement" [1]. Different things are expressed by [2] that "negative relationship between parental involvement and academic achievement in African American adolescents. They concluded that involvement forms African American parents were not good predictors of academic success in their adolescents. There is a negative relationship between parental participation in education and student academic achievement based on the two opinions above. It needs to be studied further about 
what factors can cause participation. the community is hampered by the community's participation in education so that it influences the increase and absence of student academic achievement. The effectiveness of the role of the community in the school committee is very dependent on the creativity of the institution in giving birth and carrying out forms of support for school programs. [3]. So that an in-depth study is needed to find out how the principal is prepared to implement Permendikbud number 75 of 2016 concerning school committees, what is the main obstacle for school principals and teachers in implementing Permendikbud number 75 in 2016, and what is a barrier to school committees, parents of students and the community participates in education.

\section{Methodology}

The research used is qualitative with survey methods. The research subjects consisted of the principal, teacher representatives, school committees and parents of students who were randomly selected for each school. The schools that are the subject of research are the Public Elementary School in Banda Aceh, consisting of Public Elementary School 01, Public Elementary School 02, Public Elementary School 10, Public Elementary School 53, Public Elementary School 62, and Public Elementary School 60 Banda Aceh. Data collection was carried out starting from 2017 until middle 2018 through interviews, questionnaires for seminars and Focus Group Discussions (FGD). Furthermore, the data were analyzed using the Miles and Huberman method, which consists of steps namely data reduction, data presentation and drawing/ verification of conclusions.

\section{Results And Discussion}

\subsection{Result}

Minister of Education and Culture Regulation No. 75 of 2016 concerning school committees, in implementing the policy requires an analysis of what school understanding is and what are the obstacles experienced by the school in implementing the policy. The presentation of research results related to this can be as follows:

\subsubsection{Principal Readiness in Implementing Policies on School Committees}

The implementation of the school committee's policy requires the school principal to prepare everything as stated in the related policy. Through this research, it was described how the principal's readiness in planning, implementing and evaluating related to the school committee. The principal in planning school committees starts from providing a special room / special desk for school committees in each school. The provision of special school room / desk has been carried out by all subject schools. This is in accordance with article 2 of Permendikbud Number 75 paragraph 1 which states that the school committee is located in each school. Furthermore, the principal determines the school committee members who are chosen accountably and democratically through the parent / guardian meeting of students. as many as $20 \%$ of the total $100 \%$ of the number of subject schools that have established school committee members in accordance with the rules set out in the school committee's policy relating to the elements and number of school committee members, as much as $80 \%$ still use the Decree on the Determination of the old school committee or still follow the rules school 
committee policy number 044 / U / 2002 concerning education boards and school committees. So that it can be concluded that the understanding of the school committee in implementing the number 75 school committee policy in 2016 still needs to be improved through active socialization and communication with related parties. Furthermore, the principal communicates the school program that has been planned to the school committee, with the aim that the school committee can carry out its functions in improving the quality of educational services in a mutual, democratic, independent, professional and accountable manner. (Ministry of Education and Culture, 2016). Based on the results of interviews and observations it was found that there was only one school that had successfully empowered the school committee and the school principal Mrs. Rosmawati MS stated that "as long as I became the principal in some places there was no problem with the performance of the school committee, they were all effective in carrying out their functions and duties the most important thing is how leaders can communicate well with them. School committee administrators at the school can carry out their duties even though they are not yet maximal, but the school committee's performance at the school is good as stated in article 3 paragraph (1) points a, b, c, d in accordance with Permendikbud number 75 of 2016 regarding school committees in terms of giving consideration in the determination and implementation of education policies in schools. While some other schools said that they faced obstacles to being able to include school committees in school programs due to their busyness and lack of commitment from school administrators, especially when it came to fundraising. Based on these findings it can be concluded that the communication skills of leaders to empower other parties influence the commitment of the parties involved in participating in an activity.

\subsubsection{Obstacles of School Principals and Teachers in Implementing Policies on School Committees}

Principals and teachers in implementing Permendikbud number 75 in 2016 some experienced obstacles including, (1) the economic factors of parents of students become obstacles to being able to participate in implementing the quality of education services, for parents of students who have middle to lower income, it will be very difficult to participate in school program. (2) school committees have not carried out fundraising externally outside of school, they only ask for help from student guardians with voluntary assistance in the form of money and according to the school it is very difficult to realize. (3) Still related to fundraising, the school felt pressured, scared and confused by the "Clean Sweep of Illegal Levies" regulation contained in the Presidential Regulation of the Republic of Indonesia Number 87 of 2016 concerning Extortion Saber. Principals and teachers are more cautious and even become a factor in the loss of creativity of school principals and teachers in developing school programs, they are more running tolerant school programs that have been funded by School Operational Assistance (BOS) funds, thus impacting on educational goals such as contained in the 2013 curriculum cannot be run optimally. Based on the results of the study it was found that there was a lack of understanding of the schools, especially principals, to distinguish between aid, donations and illegal fees and how to do technical activities so that each activity carried out was not included in the category of illegal payments. (4) Understanding the Principal and Teacher about the participation of school committees in schools is only related to funds (money), school committees will be invited to schools if the schools experience funding constraints, even school committees are not directly involved from the beginning in the preparation of school programs, this has an impact on the lack of commitment of the school committee to carry out their duties properly. The school principal should be more creative in communicating the involvement of the school committee and parents of students in 
the school activity program not only related to money but also the services of parents who can be empowered. (5) Understanding of schools in preparing school programs based on EMIS (School Intrenal Quality Evaluation) is still lacking. Therefore, increasing school capacity (capacity building) in developing school programs can be realized through socialization and training on policies on school committees.

\subsubsection{Obstacles of School Committees, Parents and the Community Participate in Education}

In addition to internal schools (principals and teachers) obstacles are also faced by school committees, parents and the community to be able to participate in education, including the following: (1) The commitment of the school committee is still very low in carrying out its functions and duties, in carrying out its job as a school committee must sacrifice their work time as traders, fishermen, office workers, private employees, where the work is the main job they cannot leave for a long time. Even some school committees said that we should get awards / salaries and set them in legal and written regulations, because devoting ourselves to school in helping to improve the quality of education services in schools can reduce family income because work must be abandoned. (2). The lack of understanding of the school committee regarding its duties and functions as a school committee is an obstacle to them. The school's confusion and un communication to involve the school committee in the early preparation of the school program because of the school's misunderstanding in preparing school programs is not based on EMIS so that the most priority things to run are sometimes not included in the school program, so that it becomes a problem later on. when the priority matters must be implemented immediately but the costs do not exist and the school only invites the school committee if it deals with the lack of financing (3) There is no integration of community institutions (companies, universities, community leaders, etc.) towards education in schools so that if the community has a donation fund for education sometimes they don't know where to contribute the most needy, and it seems that the donations given are not on target. So it takes a model of community participation that can collect all community assistance for education.

\subsection{Discussion}

Based on the description above, it can be stated that the implementation of the school committee's policy based on Permendikbud number 75 of 2016 is generally not in accordance with the regulations contained in this matter due to the lack of knowledge of school residents regarding the policy of Permendikbud number 75 of 2016 concerning the school committee. Where such knowledge must be trained and stimulated through socialization and training for school residents simultaneously. This is in line with the results of the study [4] which states that Knowledge Management partially does not have a significant influence on Employee Performance, while Work Ability and Attitude partially have a significant influence on Employee Performance. Simultaneously, Knowledge Management, Work Capabilities and Attitudes have a significant effect on Employee Performance.

However, the principal's efforts to empower school and community committees have been running even though they are not yet optimal, but these efforts have not touched on fundamental problems, where the commitment of school committees is still very low in participating in schools due to busyness and lack of value added factors for school committees due lack of respect for their performance. In addition, the communication skills of school principals and classroom teachers can increase the involvement of school committees to participate effectively in schools. in other words that communication influences commitment, this is in line with the results of research from [5] which states that communication has a 
positive effect on organizational commitment as evidenced by testing the hypothesis that $\mathrm{t}$ count $=2.751>\mathrm{t}$ table $=1.645$ with significance $=0.013<\alpha=0.05$ (significant). Other research results also state that organizational communication skills influence organizational commitment such as research results [6]

However, it is necessary to study to see problems in a systemic manner, where by looking systematically understanding to find fundamental problems can be used as leverage to make improvements and changes, as stated by [7] in his book that the process of finding problems includes additional interactive relationships between components are adjusted for purpose and endogenously. The problem is seen in a multi-dimensional, multi-level / scale, multi-actor, considered multi-perspective, both time dimension (past and future), and geographical (here or there). But the difference is, if ordinary analysis means you have to look for damaged components and then repair them separately. It's different from thinking that the problem system is seen in a more comprehensive manner and is looking for a meeting point of the problem which can be used as leverage in overcoming a problem. A system analysis requires you not only to look for damaged components but also relationships. The main obstacles found in the implementation of school committee policies are related to (1) lack of knowledge of school residents including school principals, teachers, and school committees on school committee policies and in planning, implementing and evaluating school programs based on synergic Internal Quality Evaluation, ( 2) communication between various related parties to coordinate has not run optimally so as to influence the lack of community participation in education and lack of commitment of school committees to be involved in the school program.

\section{Conclusion}

Based on the discussion above, it can be concluded that:

1. The readiness of the school principal in implementing Permendikbud number 75 of 2016 concerning school committees is good, in terms of providing a special room or table for school committee administrators and assigning school committee administrators even though it is not yet maximal in fulfilling the conditions in the school committee policy due to lack of understanding of the principal's knowledge of the school committee's policy so that the performance of the school committee has not been effective.

2. Obstacles of school principals and teachers in implementing Permendikbud number 75 in 2016, including (1) economic factors of parents who are less able to become obstacles to the school to involve parents in helping school programs, (2) school suit committees to help fundraising, (3) the existence of government regulation number 87 concerning saber pungli is an obstacle for schools to carry out activities that incur excessive costs, (4) understanding of principals and teachers in general regarding the performance of school committees is only related to funds in the form of money, (5) still low ability of schools to form school programs based on EMIS (School Internal Quality Evaluation).

3. Obstacles of school committees, parents and community participation in education include lack of respect for school committee performance, lack of understanding in implementing school committee policies and not synergy with school programs with committee programs, not all parties (schools, committees, communities / universities / companies) in participating to improve the quality of education services. 
Based on this sub focus, if viewed from the perspective of a system that interrelates the underlying problems that hinder the participation of school and community committees in education, there is a lack of knowledge / understanding and ineffective communication problems and synergies between various parties.

Based on the above discussion, further studies are needed relating to improving the knowledge of school residents and the integration of school communication internally and society externally in order to improve the quality of education services.

\section{Acknowledgements}

Thanks to the Ministry of Technology and Higher Education who has provided research funding for the Cooperation Research grant between University (PKPT), then to International Conference on Education and Technology (ICON-EST 2018) committee and the editorial of SCITEPRESS which has allowed this article to be published after passing several repair process so that it becomes feasible to read.

\section{References}

[1] S. Wilder, "Effects of parental involvement on academic chievement : a meta- synthesis," Educ. Rev., vol. 3, no. 66, pp. 377-397, 2014.

[2] L. Steinberg, S. Lambom, S. Dornbusch, and N. Darling, "Impact of parenting on adolescent achievement: Authoritative parenting, school involvement, and encouragement to succeed," Child Dev., vol. 66, pp. 1266-1281, 1991.

[3] P. Sumedi AS, "Kajian Implementasi Kebijakan Komite Sekolah,” Educ. Indones., vol. 18, no. 2, pp. 163-186, 2010.

[4] C. F. P. Laoh, B. Tewal, and S. G. Oroh, "Pengaruh Manajemen Pengetahuan, Keterampilan dan Sikap Kerja terhadap Kinerja Pegawai (Studi Kasus pada PT Nasional Nobu Bank Area Manado)," J. Berk. Ilm. Efisiensi, vol. 16, no. 4, pp. 786-793, 2016.

[5] F. Hanu, "Pengaruh Kepuasan Kerja dan Komunikasi terhadap Komitmen Organisasi dengan Kepemimpinan sebagai Variabel Moderasi pada STEKOM Semarang,” Nusamba, vol. 2, no. 1, 2017.

[6] M. Suliyem, "Pengaruh Komunikasi Organisasi dan Kepuasan Kerja terhadap Komitmen Organisasi Guru SD Santo Fransiskus di Lampung,” J. Manaj. Pendidik., vol. 7, 2016.

[7] A. Hidayatno, "Berpikir Sistem: Pola Berpikir untuk Pemahaman Masalah yang lebih baik," 2016. 